$11-1-2021$

\title{
Intercollegiate Athletics Marketing-Generated Revenue: Within Autonomy Football Bowl Subdivision
}

\author{
Alicia Romano \\ University of Northern Colorado, alicia.b.romano@gmail.com \\ Jamie Riggs \\ Northwestern University \\ Alan Morse \\ University of Northern Colorado \\ Yoon Tae Sung \\ University of Northern Colorado
}

Follow this and additional works at: https://trace.tennessee.edu/jasm

Part of the Finance and Financial Management Commons, and the Marketing Commons

\section{Recommended Citation \\ Romano, Alicia; Riggs, Jamie; Morse, Alan; and Sung, Yoon Tae (2021) "Intercollegiate Athletics Marketing-Generated Revenue: Within Autonomy Football Bowl Subdivision," Journal of Applied Sport Management: Vol. 13 : Iss. 1. \\ https://doi.org/10.7290/jasm137256 \\ Available at: https://trace.tennessee.edu/jasm/vol13/iss1/4}

This article is brought to you freely and openly by Volunteer, Open-access, Library-hosted Journals (VOL Journals), published in partnership with The University of Tennessee (UT) University Libraries. This article has been accepted for inclusion in Journal of Applied Sport Management by an authorized editor. For more information, please visit https://trace.tennessee.edu/jasm. 


\title{
Intercollegiate Athletics Marketing-Generated Revenue: Within Autonomy Football Bowl Subdivision
}

\author{
Alicia B. Romano \\ Jamie D. Riggs \\ Yoon Tae Sung \\ Alan L. Morse
}

\begin{abstract}
Intercollegiate athletic market-generating revenue (MGR) is of interest to administrators for increasing institution revenue. The driving factors of MGR (i.e., conference, facilities, and finances) need to be understood to allow target level planning for increasing MGR. Multiple linear regression was used to assess MGR on a sample of U.S. autonomy Football Bowl Subdivision institutions. Per capita attendance by designated marketing area, capacity, and contributions were shown to have a strong, quantifiable influence on MGR. By setting the levels of the facility and financial determinant variables, and adjusting for conference, the MGR may be predicted or targeted for institution revenue goals.
\end{abstract}

Keywords: marketing-generated revenue, intercollegiate athletics, autonomy football bowl subdivision

Alicia B. Romano is a Doctoral Teaching Assistant at the University of Northern Colorado

Jamie D. Riggs is an Adjunct Lecturer at Northwestern University

Yoon Tae Sung is an Assistant Professor at the University of Northern Colorado

Alan L. Morse is a Professor at the University of Northern Colorado

Please send correspondence to Alicia B. Romano, alicia.romano@unco.edu 


\section{Introduction}

The National Collegiate Athletic Association (NCAA) Autonomy Football Bowl Subdivision (FBS) institutions are the largest sought-after resource for corporate sponsorships, advertising, licensing, and royalties (Knights Commission, 2021). In turn, autonomy FBS intercollegiate athletic (ICA) departments rely on these external generated revenues to help minimize subsidies and the distribution of departmental revenues (Burnsed, 2015). The pressure to become more self-sufficient (Ridpath et al., 2015) is due to the reduced governmental support for state institutions (Mitchel et al., 2016). The autonomy FBS institutions can support their need to become self-sufficient by creating financial collaborations and partnerships with external organizations. Consequently, autonomy FBS institutions desire for self-sufficiency has significantly impacted the priorities, strategies, and decisions of their ICA administrators and departments.

To help ICA departments increase their external revenues, significant determinants must be determined. Previous research has examined the influence of select factors on ICA overall department-generated revenues (Caro \& Benton, 2012; Hill \& Qu, 2019; Jewel, 2020; McEvoy et al., 2013; Wanless et al., 2019). However, these studies did not focus on factors that influence a specific subset of revenue sources. Thus, determining what factors influence marketing-generated revenue sponsorships, advertisements, licensing, and royalties - can support autonomy FBS ICA administrators' decision-making and strategic planning when aligning their marketing-generated revenue agendas. Marketing-generated revenue has increased from $\$ 4.5$ million to $\$ 10.6$ million since 2015 and is projected to continue rising (NCAA, 2019b). This upward trend in marketing-generated revenue creates a sizeable benefit for ICA departments. This will help decrease ICA departmental revenue distribution and reduce subsidies. The purpose of this study is to further determine which facility, financial, and success determinants have the most significant effects on FBS ICA marketing-generated revenues.

\section{Literature Review and Hypothesis Development}

Autonomy FBS ICA departments are strategically planning how to maximize academic capitalism and revenue sources considering decreasing state funds (Slaughter \& Rhoades, 2009). The theory of academic capitalism views ICA departments as a function of the institution that generates revenue to support the institution's goal of self-sufficiency (Slaughter \& Rhoades, 2009). They rely on athletic directors to actively seek licensing deals and corporate sponsorships to operate and sustain their athletic programs (Greenberg, 2008). As state funds decrease, institutions become dependent on ICA departments to maximize revenue generation (Burnsed, 2015), which has a significant impact on ICA departments decision-making processes.

Intercollegiate athletic departments can utilize facility, financial, and success determinants to potentially help increase marketing-generated revenue. Facility determinants are captured by the attendance and capacity of stadiums and arenas. It can be suggested that attendance will increase corporations' recognitions, which has a positive effect on brand awareness (Kang et al., 2019; Weight et al., 2010). The visibility of corporate partnerships and in-venue signage creates a large amount of awareness (Pierce \& Petersen, 2011). Additionally, collegiate sport organizations can attract more marketing-generated revenue sources by identifying marketing areas around sport institutions (e.g., Texas A \& M's designated marketing area is Waco-Temple-Bryan) (Dilys \& Gargasas, 2014). These event-related target markets are a key criterion for marketing-generated revenue sources (Turgeon \& Colbert, 1992). Further, the potential audience represents a facilities capacity and is one variable sponsors use as an indicator of potential consumer awareness (Gerrard et al., 2007). The larger the capacity the better chance of increasing consumer awareness and corporate partnership recognition, which could create more incentive for marketing-generated revenue. Thus, the following two hypotheses were generated:

$H^{1}$ : An increase in per capita attendance by designated marketing area for football and men's basketball increases marketing-generated revenues.

$H^{2}$ : An increase in capacity of football stadiums and men's basketball arenas increases marketing-generated revenues.

Financial determinants are captured by donor contributions and competition guarantees. Donor contributions generated 22.7\% of Division I FBS revenue in 2019 (NCAA, 2019b) and help build/renovate sports facilities (e.g., Missouri Football, 2017) to incorporate more sponsorship opportunities (Cohen, 2012). Facilities with more spectator-friendly amenities (i.e., modern structure, state-of-the-art equipment), has translated into better sponsorships deals due to increased ticket sales 
(Palmero \& Price, 2015). Additionally, competition guarantees contribute to autonomy FBS teams winning percentage and potential bowl eligibility (Berkowitz, 2017; Kirshner, 2016; Lillig, 2009). Competition guaranteed revenue depends upon conference affiliation, which has a strong effect on generated revenues (McEvoy et al., 2013). Thus, the following two hypotheses were generated:

$H^{3}$ : An increase in donor contributions increase marketing-generated revenues.

$H^{4}$ : Competition guarantees increase marketing-generated revenue.

Success determinants are captured by a team's overall winning percentage. Football and men's basketball winning percentages, along with postseason appearances, have a strong correlation to overall generated revenue (McEvoy et al., 2013). Winning percentages also increase the amount of exposure marketing companies gain (Arthur, Dolan, \& Cole, 1998; Jensen, 2012; Pruitt, Cornwell, Clark, 2004). Thus, the following hypothesis is proposed:

$H^{5}$ : Increasing overall winning percentage for football and men's basketball arenas increase marketing-generated revenue.

\section{Data}

\section{Methods}

The sample consists of 52 public autonomy FBS institutions, 75\% of all autonomy FBS institutions, over five years from 2015 to 2019. This study's sample period was based on autonomy institutions last conference realignment in 2014 and before COVID-19 disrupted sports in 2020. The sample period was similar to previous methods (McEvoy et al., 2013). The private institutions were excluded due to non-legal obligations. This exclusion is noted as a generalizable limitation of the study. Additionally, since autonomy FBS football and men's basketball create the highest generating revenue (Drozdowski, 2020), this study focuses on these two major sports. After including all explanatory variables, including categorical variables, the resulting sample size was 2,860 .

\section{Model}

A multiple linear regression (MLR) analysis was employed as the primary statistical method, which is considered an ideal methodology for estimating the determinants of generated revenue (McEvoy et al., 2013). Researchers employing this approach can investigate the effects of various determinant factors on marketing-generated revenue. The model assumptions and multicollinearity were examined, after which a final model was created using a square root transformation to make the residuals normally distributed. This square root transformation $\left(y^{\wedge} 0.5\right)$ was determined based on the Box-Cox transformation lambda value of 0.4 with $95 \%$ confidence interval $(0.2,0.5)$ which contains 0.5 . Conference and year were used as indicator variables in the MLR model. Each hypothesis was tested for a slope of zero, with a significance level of 0.05 . The model equation below represents the MLR model of marketing-generated revenue used in the present study.

$$
\begin{gathered}
\mathrm{E}\left(\mathrm{MGR}_{\mathrm{i}}\right)=b 0+b 1 \mathrm{CON}+b 2 \text { YEAR }+b 3 \text { FBPCADMA + b4BBPCADMA + b5FBCCAP + b6BBCAP + } \\
b 7 \text { DONORCONT }+b 8 \text { COMPGUAR }+b 9 \text { FBOVRWIN }+b 10 \mathrm{BBOVRWIN}
\end{gathered}
$$

\section{Dependent Variable (MGR)}

MGR represents the annual marketing-generated revenues for autonomy FBS athletic programs. An important contribution of this study is the use of generated revenue from only corporate sponsorship, licensing, royalties, and sale of advertisements, rather than the USA today revenues which include broadcasting contracts, e-commerce rights, and NCAA revenue sharing), or total revenues including student fees and department subsidizations. Data for this variable were collected from the Knights Commission on Intercollegiate Athletics database compiled by the Knight Foundation, which compiles Division I revenue and expense reports for over 200 public institutions. 


\section{Determinant Variables}

Per capita attendance by DMA (FBPCADMA, BBPCADMA). FBPCADMA represents per capita football attendance by its designated marketing area. This variable was measured by the average annual football stadium attendance divided by the average measurement of local television viewings within the stadium's geographical region in the United States. BBPCADMA represents per capita basketball attendance by its designated marketing area. This variable was measured by the average annual basketball arena attendance divided by the average measurement of local television viewings within the arena's geographical region in the United States. Data for attendance were collected through a database published in NCAA, while data for DMA were collected through the Nielsen DMA Rankings database published in Media Track Communication. The Nielsen DMA rankings data is based on the population of each surveyed market region. These DMAs range across the entire U.S. and consist of multiple or split counties that do not overlap.

Capacity (FBCAP, BBCAP). FBCAP represents the average annual football stadium capacity. BBCAP represents the average annual basketball arena capacity. Data for this variable were collected from each institutional website individually.

Donor contributions (DONORCONT). DONORCONT represents the average annual intercollegiate athletic donor contributions that are funded by associations, clubs, corporations, foundations, individuals, or other organizations external to the athletics program above the face value for tickets. Data for this variable were collected from the Knights Commission database.

Competition guarantees (COMPGUAR). COMPGUAR represents the annual average dollar amount universities gain when non-conference contests are played between Power Five institutions and lower-level institutions (i.e., FCS, Division II). Data for this variable were collected from the Knights Commission database.

Overall winning percentage (FBOVRWIN, BBOVRWIN). FBOVRWIN represents the overall winning percentage of the universities football teams. BBOVRWIN represents the overall winning percentage of the university men's basketball teams. The overall winning percentage includes all in-season games along with tournament or bowl appearances. Although post-season games (tournament and bowl appearances) will change a team's winning percentage either positively or negatively, it is a part of a team's final standings. Data for these variables were collected from the ESPN database.

\section{Results}

Table 1 presents the descriptive statistics for the dependent and explanatory variables that were analyzed. This table includes 206 observations over 5 years (2015-2019). Additionally, Table 2 displays the correlation coefficients between the predictor variables. The correlations between predictor variables were noted as a possible indication of multicollinear. Thus, a multicollinearity test was run, and there were no signs of multicollinearity between predictor variables (the VIF values were very low), see Table 3.

\section{Multiple Linear Regression Analysis}

Table 3 presents the MLR modeling results for marketing-generated revenue and Table 4 presents the Tukey comparison by conference. The F-statistic was $17.35(d f=240$, $p$-value $<2.2 \mathrm{e}-16)$, with an $R^{2}$ value of 0.57 and an adjusted $R^{2}$ value of 0.55 . Thus, the regression model explained $55 \%-57 \%$ of the variance in generated revenues. These results are similar to the level of variance explained by the Bowl Championship Series conference affiliation (ACC, Big 12, Big East, Big 10, Pac 12, and SEC) in overall department-generated revenue (McEvoy et al., 2013). We believe that our variation level is slightly less due to the usage of only marketing related revenue sources and the non-usage of the Big East since it is not considered one of the autonomy FBS institutions.

Five determinants were hypothesized to increase marketing-generated revenue. Of the five variables (see Table 3), FBPCADMA, FBCAP, and DONORCONT were found to be statistically significant factors in marketing-generated revenue. Comparatively, BBPCADMA, BBCAP, COMPGUAR, FBOVRWIN, and BBOVRWIN were not found to be statistically significant. 
Table 1

Descriptive Statistics for the Dependent and Independent Variables

\begin{tabular}{lcccc}
\hline Variable & Mean & SD & Min & Max \\
\hline Dependent Variable & & & & 47184531 \\
$\quad$ MGR & 10904890 & 7451851 & 1235397 & 0.878 \\
Facility Determinants & & & 0.241 \\
FBPCADMA & 0.173 & 0.169 & 0.004 & 109.900 \\
BBPCADMA & 0.030 & 0.034 & 0.001 & 23.000 \\
FBCAP & 70.190 & 19.074 & 32.740 & 94.175 \\
BBCAP & 14.270 & 3.638 & 8.000 & 6.540 \\
Financial Determinants & & & & 1.000 \\
DONORCONT & 26.958 & 14.053 & 6.618 & 0.921 \\
COMPGUAR & 1.032 & 1.346 & 0.000 & \\
Success Determinants & & & 0.000 & 0.156 \\
FBOVRWIN & 0.556 & 0.214 & 0.148 & \\
BBOVRWIN & 0.602 & & & \\
\hline
\end{tabular}

Note. Factor variables not included.

Table 2

Correlation Table

\begin{tabular}{lcccccccc}
\hline & FB & BB & & & & FB & BB \\
& PCA & PCA & FB & BB & DONOR & COMP & OVR & OVR \\
Variables & DMA & DMA & CAP & CAP & CONT & GUAR & WIN & WIN \\
\hline FBPCADMA & 1.00 & 0.80 & 0.29 & -0.12 & 0.28 & 0.05 & 0.10 & 0.07 \\
BBPCADMA & 0.80 & 1.00 & 0.00 & 0.12 & 0.04 & -0.05 & -0.12 & 0.19 \\
FBC & 0.29 & 0.00 & 1.00 & 0.06 & 0.62 & 0.30 & 0.40 & 0.01 \\
BBC & 0.10 & 0.12 & 0.06 & 1.00 & -0.02 & 0.06 & -0.08 & 0.24 \\
DC & 0.28 & 0.04 & 0.62 & -0.02 & 1.00 & 0.15 & 0.29 & 0.10 \\
CG & 0.04 & -0.05 & 0.30 & 0.06 & 0.15 & 1.00 & 0.17 & 0.08 \\
FBOW & 0.62 & -0.12 & 0.40 & -0.08 & 0.29 & 0.17 & 1.00 & -0.05 \\
BBOW & -0.02 & 0.19 & 0.01 & 0.24 & 0.10 & 0.08 & -0.05 & 1.00 \\
\hline
\end{tabular}


Table 3

Multicollinearity VIF Test

\begin{tabular}{|c|c|c|c|c|c|c|c|c|c|c|}
\hline & & & $\mathrm{FB}$ & $\mathrm{BB}$ & & & & & FB & $\mathrm{BB}$ \\
\hline & & & PCA & PCA & $\mathrm{FB}$ & $\mathrm{BB}$ & DONOR & COMP & OVR & OVR \\
\hline & Con & Year & DMA & DMA & CAP & CAP & CONT & GUAR & WIN & WIN \\
\hline VIF & 1.105 & 1.005 & 2.284 & 2.166 & 1.588 & 1.185 & 1.410 & 1.078 & 1.126 & 1.086 \\
\hline
\end{tabular}

Table 4

Marketing-Generated Revenue MLR Results

\begin{tabular}{|c|c|c|c|c|}
\hline Variable & Coefficients & Std Error & $t$-value & $p$-value \\
\hline Intercept & -455.177 & 346.244 & -1.286 & 0.200 \\
\hline CON2 (Big 12) & 338.192 & 160.501 & 2.107 & $0.036^{\star}$ \\
\hline CON3 (Big 10) & 489.320 & 153.354 & 3.191 & $0.002^{\star \star}$ \\
\hline CON4 (Pac 12) & 1043.650 & 155.454 & 6.714 & $0.000^{\star \star \star}$ \\
\hline CON5 (SEC) & -387.751 & 162.870 & -2.381 & $0.018^{\star}$ \\
\hline YEAR16 & 121.976 & 137.755 & 0.885 & 0.377 \\
\hline YEAR17 & 229.497 & 138.653 & 1.655 & 0.099 \\
\hline YEAR18 & 405.241 & 140.455 & 2.885 & $0.004^{\star \star}$ \\
\hline YEAR19 & 532.087 & 138.981 & 3.828 & $0.000^{\star \star \star}$ \\
\hline \multicolumn{5}{|l|}{ Facility Determinants } \\
\hline FBPCADMA & -4347.466 & 1543.718 & 2.301 & $0.022^{\star}$ \\
\hline BBPCADMA & -44271.609 & 27794.251 & 1.750 & 0.081 \\
\hline FBCAP & 37.864 & 3.826 & 9.896 & $0.000^{\star \star \star}$ \\
\hline BBCAP & 27.464 & 15.815 & 1.737 & 0.084 \\
\hline \multicolumn{5}{|c|}{ Financial Determinants } \\
\hline DONORCONT & 21.629 & 4.394 & 4.922 & $0.000^{\star \star \star}$ \\
\hline COMPGUAR & -40.663 & 20.303 & -0.230 & 0.818 \\
\hline \multicolumn{5}{|l|}{ Success Determinants } \\
\hline FBOVRWIN & -305.947 & 233.242 & -1.312 & 0.191 \\
\hline BBOVRWIN & -217.490 & 331.473 & -0.656 & 0.512 \\
\hline
\end{tabular}

Note. ${ }^{*} p<0.05,{ }^{* *} p<0.01,{ }^{* *} p<0.001$ 
Table 5

Tukey Comparison by Conference

\begin{tabular}{|c|c|c|c|c|}
\hline Variable & Coefficients & Std Error & $t$-value & $p$-value \\
\hline \multicolumn{5}{|l|}{ Conference } \\
\hline Big $12-\mathrm{ACC}$ & 338.2 & 160.5 & 2.107 & 0.21907 \\
\hline Big $10-$ ACC & 489.3 & 153.4 & 3.191 & $0.01377^{\star}$ \\
\hline Pac 12 - ACC & 1043.7 & 155.5 & 6.714 & $<0.001^{\star \star \star}$ \\
\hline SEC - ACC & -387.8 & 162.9 & -2.381 & 0.12327 \\
\hline Big 10 - Big 12 & 151.1 & 153.1 & 0.987 & 0.85996 \\
\hline Pac 12 - Big 12 & 705.5 & 160.6 & 4.393 & $<0.001^{\star \star \star}$ \\
\hline SEC - Big 12 & -725.9 & 155.0 & -4.684 & $<0.001^{\star \star \star}$ \\
\hline Pac 12 - Big 10 & 554.3 & 153.5 & 3.612 & $0.00338^{\star \star}$ \\
\hline SEC - Big 10 & -877.1 & 140.8 & -6.229 & $<0.001^{\star \star \star}$ \\
\hline SEC - Pac 12 & -1431.4 & 170.9 & -8.378 & $<0.001^{\star \star \star}$ \\
\hline
\end{tabular}

Note. ${ }^{\star} p<0.05,{ }^{\star *} p<0.01,{ }^{\star * *} p<0.001$

\section{Discussion and Implications}

This study examined determinants of autonomy FBS ICA marketing-generated revenues. The determinants found to increase marketing-generated revenue can help autonomy FBS ICA departments determine how to best support their institution. Findings from this study are beneficial for ICA administrators' budgeting and financial activities. First, similar to McEvoy et al. (2013), conference affiliation was found to be strongly correlated with marketing-generated revenue. Conference affiliation should be taken into consideration when ICA departments determine their in-facility corporate marketing strategies (Table 3). For example, autonomy FBS institutions such as the Big 10 and Pac 12 should cater their partnership strategies towards marketing-generated revenue sources, while the SEC may need to cater more towards other generated revenues (i.e., media and broadcasting).

Regardless of conference affiliation, however, football stadium capacity and per capita attendance by DMA increase marketing-generated revenue for all autonomy FBS ICA programs $\left(\mathrm{H}^{1}, \mathrm{H}^{2}\right)$. These football in-facility determinants are due to the increased consumer awareness of sponsorship brands, which attracts more marketing-generated revenue sources. As DMA's are becoming more significant due to increased digital marketing engagement by consumers (Tiago et al., 2014), marketing managers should adopt more marketing strategies on digital platforms that can include both in-person and online viewers. Additionally, this study found that autonomy FBS institutions should rely more on men's football than basketball to increase their marketing-generated revenue. This disparity may be due to the wider range of football stadium capacities/attendance than men's basketball (Table 1). Regardless, autonomy FBS football operates and sustains ICA programs' marketing-generated revenue, which functions to support the institution's goal of self-sufficiency (Slaughter \& Rhoades, 2009). Thus, ICA marketing strategies should lean on football capacity, attendance, and viewer numbers as incentives for corporate partnership deals. Part of the capacity and attendance numbers may be influenced by the facilities ability to create more 'spectator friendly amenities' (Palmero \& Price, 2015). Intercollegiate athletic departments should allocate funds towards 'spectator friendly amenities' to increase marketing-generated revenue.

Donor contributions also increase marketing-generated revenue for autonomy FBS ICA programs $\left(\mathrm{H}^{3}\right)$. The usage of donor contributions to expand sponsorship opportunities creates higher consumer awareness and brand association (Pierce \& Petersen, 2011). Thus, ICA departments should allocate donor contributions towards 'building sponsors into the design of spectator facilities' (Cohen, 2012). Additionally, ICA administrators should use donor contributions to create 
Intercollegiate Athletics MGR

more 'spectator friendly amenities', which will increase corporate partnership deals and ticket sales. In the future, administrators should shift their facility design, which can help increase consumer attendance and be used as an incentive for corporate partners to increase their brand awareness and return on investment.

\section{Limitations and Future Research}

Although the proposed model explained approximately $55 \%$ of the variance, a limitation of the current study is the exclusion of additional variables that may significantly influence marketing-generated revenue. Future studies could examine how broadcast and media revenues affect marketing-generated revenue. Additionally, this current study focused on autonomy FBS institutions. Future studies could also examine the difference in marketing-generated revenues across autonomy and non-autonomy FBS institutions. Statistical analysis could compare influencing factors between these two groups related to their marketing-generated revenues. Another area for future study is to further investigate the relationship between competition guarantees and winning percentages or post-season seeding of autonomy FBS institutions.

\section{References}

Arthur, D., Dolan, G. \& Cole, M. (1998) The benefits of sponsorship success: an analysis of the relationship between television exposure and the position of a motorcycle rider. Cyber-Journal of Sport Marketing, 2(2), 1-15.

Berkowitz, S. (2017, August 29). This year's 'guarantee games' worth $\$ 150$ million for college football programs. Retrieved from https://www.usatoday.com/story/sports/ncaaf/2017/08/29/guarantee-games-worth-150-million-collegefootball-programs/608668001/

Burnsed, B. (2015). Athletics departments that make more money than they spend still a minority. Retrieved from http:// www.ncaa.org/about/resources/media-center/news/athletics-departments-make-more-they-spend-still-minority

Caro, C. A., \& Benton, C. F. (2012). The great divide: Examining football revenue among FBS schools. International Journal of Sports Science \& Coaching, 7(2), 345-369.

Cohen, A. (2012). Building sponsors into the design of spectator facilities. Retrieved from https://www.athleticbusiness. com/Fundraising/building-sponsors-into-the-design-of-spectator-facilities.html

Dilys, M., \& Gargasas, A. (2014). Structural business model based on cooperation between sports organizations and sponsors. Engineering Economics, 25(1), 94-102.

Dolphin, R. R. (2003). Sponsorship: perspectives on its strategic role. Corporate Communications: An International Journal, 8(3), 173-186.

Drozdowski, M. J. (2020, November 16). Do colleges make money from athletics? Retrieved from https://www.bestcolleges.com/blog/do-college-sports-make-money/\#:囚:text=Basketball\%2C\%20particularly\%20the\%20annual\%20March,through\%20TV\%20and\%20marketing\%20rights.

Fulks, D. L. (2019). 2004-2019 NCAA revenue and expenses of Division I intercollegiate athletic programs report. Indianapolis, IN: National Collegiate Athletic Association.

Gerrard, B., Parent, M. M., \& Slack, T. (2007). What drives the value of stadium naming rights? A hedonic-pricing approach to the valuation of sporting intangible assets. International Journal of Sport Finance, 2(1), 10-24.

Greenberg, M. (2008). College athletics - Chasing the big bucks. For the Record, 19(2), 6-10.

Hill, W, W., II, \& Qu, Y. (2019). College Football Performance and Athletic Department Revenues: The Power of Winning Tradition. Journal of Marketing Development \& Competitiveness, 13(2), 31-41.

Jewell, R. T. (2020). NCAA Expenditure and Efficiency: Analyzing Generated and Allocated Revenue in the Football Bowl Subdivision. Journal of Sports Economics, 21(4), 363-390.

Kang, S., Yang, M., \& Kim, J. (2019). The effects of sports sponsorship recognition on corporate image, purchasing intention and brand identification. Journal of Distribution Science, 17(10), 49-59.

Kirshner, A. (2016). College football's cupcake games are about more than just easy wins. Retrieved from https://www. sbnation.com/college-football/2016/6/22/11648368/scheduling-cupcake-guarantee-games-cost

Knight Commission on Intercollegiate Athletics. (2021). Knight Commission on Intercollegiate Athletics. Retrieved from http://www.knightcommission.org

Lillig, J. (2009). "Magic" or misery?: HBCUs, guarantee contracts, and public policy. DePaul Journal of Sports Law, 6(1), $41-72$. 
Jensen, J. A. (2012). The importance of winning: An analysis of the relationship between an athlete's performance and sponsor exposure during televised sports events. International Journal of Sports Marketing and Sponsorship, 13(4), 282-293.

McEvoy, C., Morse, A., \& Shapiro, S. (2013). Factors influencing collegiate athletic department revenues. Journal of Issues in Intercollegiate Athletics, 6, 249-267.

Missouri Football. (2017, February 13). Mizzou Athletics Receives Record Ninth, Seven-Figure Gift for Football Facility. Retrieved from https://mutigers.com/news/2017/2/13/mizzou-athletics-receives-record-ninth-seven-figuregift-for-football-facility.aspx

Mitchel, M., Leachman, M., \& Masterson, K. (2016). Funding down, tuition up: State cuts to higher education threaten quality and affordability at public colleges. Center on Budget and Policy Priorities. Retrieved from http://www. cbpp.org/research/state-budgetand-tax/funding-down-tuition-up

NCAA. (2019a). Finances of Intercollegiate Athletics. Retrieved from http://www.ncaa.org/about/resources/research/ finances-intercollegiate-athletics

NCAA. (2019b, September 22). Finances of intercollegiate athletics database. Retrieved from https://www.ncaa.org/ about/resources/research/finances-intercollegiate-athletics-database

Palmero, M., \& Price, K. (2015). Influence of facility atmospherics on spectator attendance. Journal of Facility Planning, Design, and Management, 3(1), 44-56.

Pierce, D., \& Petersen, J. (2011). Corporate sponsorship activation analysis in interscholastic athletics. Journal of Sponsorship, 4(3), 272-286.

Pruitt S. W., Cornwell T. B. \& Clark J. M. (2004) The NASCAR phenomenon: auto racing sponsorships and shareholder wealth. Journal of Advertising Research, 44(3), 281-296.

Ridpath, D. B., Porto, B., Gurney, G., Lopiano, D., Sack, A., Willingham, M., and Zimbalist, A. (2015). Position statement: Student fee and institutional subsidy allocations to fund intercollegiate athletics. The Drake Group. Retrieved from https://drakegroupblog. files.wordpress.com/2015/04/position-statement-student-fees-final-3-2-15. pdf

Slaughter, S., \& Rhoades, G. (2009). Academic capitalism and the new economy: Markets, state, and higher education. Baltimore, MD: Johns Hopkins University Press.

Tiago, M. T. P. M. B., \& Veríssimo, J. M. C. (2014). Digital marketing and social media: Why bother? Business Horizons, 57(6), 703-708.

Turgeon, N., \& Colbert, F. (1992). The decision process involved in corporate sponsorship for the arts. Journal of Cultural Economics, 16(1), 41-51.

Wanless, L., Watanabe, N. M., Lawrence-Benedict, H. J., \& Fodor, A. (2019). Contextualizing the Financial Disparity Discussion: Modeling Power Five and Group of Five Athletic Revenues. Journal of Issues in Intercollegiate Athletics, 12, 22-45.

Weight, E., Taylor, K., \& Jacquelyn, C. (2010). Corporate motives for sport sponsorship at mid-major collegiate athletic departments. Journal of Issues in Intercollegiate Athletics, 3, 119-130.

Wells, D., Southall, R., Stotlar, D., \& Mundfrom, D. (2005). Factors related to annual fundraising contributions from individual donors to NCAA Division 1-A institutions. International Journal of Educational Advancement, 6(1), $3-10$. 